\title{
Isolation and Identification of Lipase-producing Bacteria from Oil-Contaminated Soils
}

\author{
Khaing Phyo Wai ${ }^{1}$, Weine Nway Nway Oo ${ }^{2}$ \\ ${ }^{1}$ Department of Biotechnology, Mandalay Technological University, Mandalay Region, Republic of the Union of Myanmar \\ ${ }^{2}$ Department of Biotechnology, Technological University (Kyaukse), Kyaukse, Republic of the Union of Myanmar
}

\begin{abstract}
In the present study, the indigenous microbes from oil-contaminated soil samples of oil processing mills were isolated based on their lipolytic activities. The isolated bacteria were screened on lipid-enriched media with different substrates and were selected the strains showing lipolytic activity. To be confirmed the lipase activity, the strains were further examined on olive oil and rhodamine B media. And then, the best lipase producer strains were further identified by $16 S$ rDNA sequencing method. Based on the 16S rDNA sequencing results, the strains were close to Acinetobacter species and Stenotrophomonas species.
\end{abstract}

Keywords: oil-contaminated soil, lipase, olive oil, 16S rDNA sequencing method

\section{Introduction}

The large part of the earth's biomass is represented by lipids. Lipids are essential to all living systems. They are the most important source of energy, play structural roles in membranes and are involved in signaling events. To be able to carry out these functions, lipids require lipolytic enzymes during their metabolism. Lipolytic enzymes catalyze the turnover of these water-insoluble compounds [1]. They also breakdown lipids and make them mobile within the cells of individual organisms [2]. Lipolytic enzymes are grouped into 3 main categories, which are esterases, phospholipases and lipases [3].

Lipases are defined basically as fat-splitting enzymes that catalyze the hydrolysis of long-chain triacylglycerols to from glycerols and fatty acids in the presence of excess water. Also, they can catalyze the reverse reaction, synthesis of triacylglycerols, under non-aqueous conditions [4]. Lipases occur widely in nature, but commercially useful lipases are usually obtained from microorganisms that produce a wide variety of extracellular lipases. Microbial lipases are more widely applied in industries due to their shorter generation time; ease of bulk production which is further enhanced with advancement in fermentation technologies; and ease of manipulation, either genetically or environmentally. Lipaseproducing microorganisms have been found in diverse habitats such as industrial wastes, vegetable oil processing factories, diaries, soil contaminated with oil, etc [5]. Many microorganisms such as bacteria, yeast and fungi are known to secrete lipases. Of all these, bacterial lipases are more economical and stable [6]. Bacterial lipases are used extensively in food and dairy industry for the hydrolysis of milk fat, cheese ripening, flavor enhancement and lipolysis of butter fat. The industrial demands for new sources of lipases with different enzymatic characterstics that could create novel applications stimulate the isolation and selection of new strains of lipolytic microorganisms. We were interested in this topic because isolation of new lipase-secreting bacteria and study of their enzyme production, purification and characterization could provide new lipase with better quality and wider range of applications.

\section{Materials and Methods}

\section{A. Chemicals}

Tributyrin and $p$-nitrophenyl palmitate (pNPP) were purchased from sigma (USA). The other chemicals were also of analytical grade. Olive oil used for lipase production was commercially available in local market.

\section{B. Methods}

\section{1) Collection of sample}

Oil-contaminated soil samples from the local oil mills in Myanmar were collected and stored in sterile plastic bags. The samples were transferred to the laboratory under sterile conditions and stored at $4^{\circ} \mathrm{C}$ until examination.

\section{2) Isolation of lipolytic bacteria}

The isolation was primely processed by serial dilutions of samples and spread plate method on tributyrin agar medium. The composition of tributyrin agar medium is (per liter) $5 \mathrm{~g}$ of peptone, $3 \mathrm{~g}$ of yeast extract, $10 \mathrm{ml}$ of tributyrin and $15 \mathrm{~g}$ of agar. The $\mathrm{pH}$ of the medium was adjusted to 7 with $0.1 \mathrm{M}$ $\mathrm{NaOH}$. The culture plates were incubated at $35^{\circ} \mathrm{C}$ for $48 \mathrm{hrs}$. This medium was chosen for selectively isolating colonies capable of growing on lipid enriched medium and showing clear zones around them. Colonies showing clear zone diameters were picked up as lipolytic positive strains and streaked onto the nutrient media as pure cultures. Then, these strains were also examined on different enriched media with two different substrates such as egg- yolk and tween 80 . On these media, 14 out of 28 strains showed lipolytic activities. These potential lipolytic strains were observed under the microscope and then used for further processes.

\section{3) Screening of lipase producing bacteria}

In addition to lipases, esterases are also grouped into hydrolases. Esterases break ester bonds of short-chain fatty acids whereas lipases catalyze the hydrolysis of long-chain fatty acids that are insoluble or poor soluble. Therefore, the lipase must be capable of identifying an insoluble or aggregated substrate. Esterase activity is found to be highest towards more water soluble substrate [7].Olive oil has the 


\section{International Journal of Science and Research (IJSR) \\ ISSN (Online): 2319-7064}

Index Copernicus Value (2015): 78.96 | Impact Factor (2015): 6.391

advantage of including high concentration of oleic acid and being more economical. The lipolytic positive strains were further screened for lipase activity by using the modified rhodamine-B agar media consisting of olive oil as substrate at $35^{\circ} \mathrm{C}$. The lipase activity was detected by the presence of pink or orange colored colonies and by fluorescence under UV light.

\section{4) Characetrization and molecular identification of bacteria}

The cultures were then characterized morphologically based on Bergey's manual of systemic bacteriology. The identifications were confirmed by using nucleotide sequence analysis of $16 \mathrm{~S}$ rDNA genes. The genomic DNA was isolated from the bacteria by the DNA extraction method described by Hosek et al. [8]. 16S rRNA gene of isolated strain was amplified from its genomic DNA using a pair of universal bacterial primer, 10F (5'- AGTTTGATCCTGGCTC - 3') as forward primer and 800R (5'- CTACCAGGGTATCTAAT $\left.3^{\prime}\right)$ as reverse primer. The highly purified DNA was then amplified in a thermocycler at conditions: 35 cycles of $95^{\circ} \mathrm{C}$ for 30 seconds, $56^{\circ} \mathrm{C}$ for 30 seconds and $72^{\circ} \mathrm{C}$ for 1 min [9]. PCR products were visualized by agarose gel electrophoresis. DNA sequencing was performed in a highly automated gene sequencer. These sequences had been submitted to the GenBank database (BLASTN) and compared with the other sequences to analyze the bacterial classes and their phylogenies.

\section{Results and Discussion}

\subsection{Isolation of lipolytic strains}

Soil samples taken from oil mills in Myanmar were examined for the presence of lipolytic strains. Oil-contaminated soils were chosen as sample sources because they could be good environment for the habitats of lipid degrading bacteria and are rich of lipid. A total of 28 morphologically distinct strains (L1- L28) which showed clear zones around the colonies were isolated from oil-contaminated soils by using tributyrin agar media (Fig.1 (a)).

The egg-yolk suspension allows for the detection of lecithinase and lipase activity. Lipase destroys the fats within the egg yolk, which results in greenish blue colour of the colony surface when flooded with copper II sulphate solution (Fig 1 (b)).

Tweens (fatty acid esters of polyoxyethylene sorbitan) have been the most widely used substrates for the detection of lipase/esterase producing microorganisms in agar media. Screening using tween agar plates shows precipitation around the lipase/esterase producing micro-organisms. The method is based on the precipitation as the calcium salt of the fatty acids released by hydrolysis of tweens. Liberated fatty acids bind with the calcium incorporated into the medium. The calcium complex is visible as insoluble crystals around the inoculation site. On Tween 80 agar plates, formation of precipitation by the isolates also confirmed that this bacterial strains possessed lipolytic activity (Fig 1 (c)).
Totally, 14 strains showed lipolytic activity on these screening media and their microscopic morphology was shown in (Table 1).

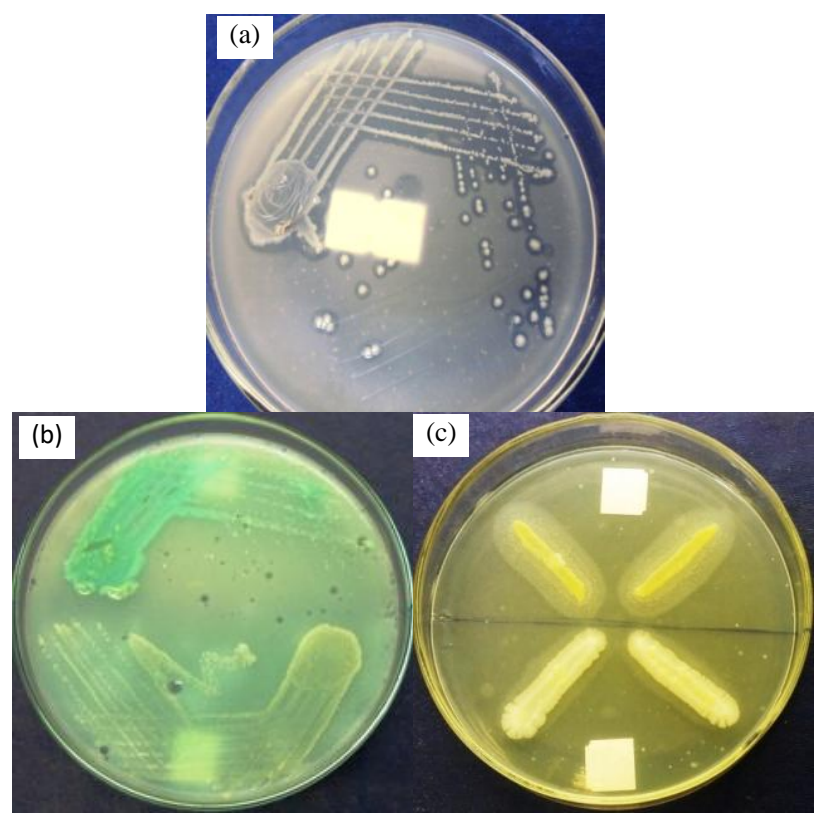

Figure 1: Screening of Lipolytic activity on (a) tributyrin agar medium (b) egg-yolk medium (c) tween 80 medium

Table 1: Cell morphology and physiology of the isolates

\begin{tabular}{|c|c|c|}
\hline Isolate & Shape & Gram's stain \\
\hline L1 & Rod & Positive \\
\hline L3 & Diplococcoid rod & Negative \\
\hline L5 & Rod & Positive \\
\hline L8 & Cocci & Positive \\
\hline L10 & Cocci & Positive \\
\hline L11 & Rod & Positive \\
\hline L12 & Rod & Positive \\
\hline L13 & Rod & Positive \\
\hline L14 & Diplococcoid rod & Negative \\
\hline L16 & Rod & Negative \\
\hline L17 & Rod & Negative \\
\hline L19 & Rod & Negative \\
\hline L20 & Diplococcoid rod & Negative \\
\hline L25 & Rod & Negative \\
\hline
\end{tabular}

\subsection{Screening of lipase positive bacteria}

Lipase producer strains were identified by the formation of orange fluorescent halos around the colonies when olive oil rhodamine B spread plates incubated at $35^{\circ} \mathrm{C}$ were exposed to UV light at $350 \mathrm{~nm}$. Olive oil is used as lipase substrate and rhodamine $\mathrm{B}$ is the indicator of lipase activitiy. This method is not sensitive to $\mathrm{pH}$ changes and does not inhibit the growth of bacteria. Seven out of 14 strains were shown the best lipase activity (Fig.2). These rhodamine B-olive oil media can identify lipase-producing bacteria from esteraseproducing bacteria. They were selected as the best lipase producer strains and used for further identification. Some biochemical properties of the selected bacteria were also shown in (Table 2). 


\section{International Journal of Science and Research (IJSR) \\ ISSN (Online): 2319-7064}

Index Copernicus Value (2015): 78.96 | Impact Factor (2015): 6.391

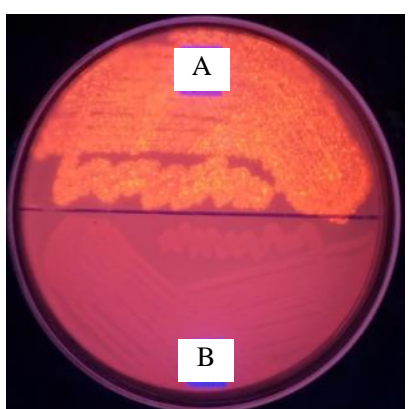

Figure 2: Screening of lipase positive strains under the UV light (A) lipase positive control (B) lipase negative control

Table 2: Some biochemical properties of the isolates

\begin{tabular}{|c|c|c|c|}
\hline Strain & Catalase & Oxidase & Lecithinase \\
\hline L3 & + & - & + \\
\hline L14 & + & - & + \\
\hline L16 & + & - & + \\
\hline L17 & + & - & + \\
\hline L19 & + & - & + \\
\hline L20 & + & - & + \\
\hline L25 & + & - & + \\
\hline
\end{tabular}

\subsection{Characterization of lipase positive strains}

Upon the amplification of $16 \mathrm{~S}$ rDNA sequence using the primers, the amplified products of $800 \mathrm{bp}$ were obtained (Fig.3) which were then sequenced and compared with the Genbank databases using BLASTN program. It was found to have 95-98\% identity with L3 and L14 strains to Acinetobacter pitti, L16, L17, L19 and L25 strains to Stenotrophomonas maltophilia, L20 strain to Acinetobacter baumannii in (Table 3).

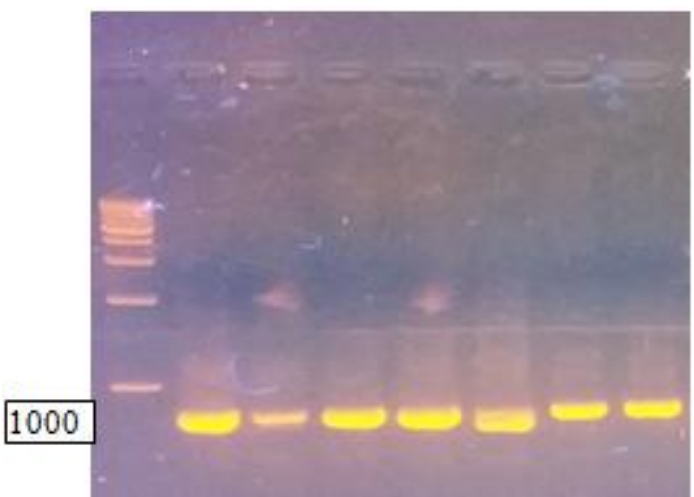

Figure 3: Colony PCR result. Line1: $1 \mathrm{~kb}$ DNA ladder. Line2: 800bp PCR products

Table 3: Sequencing result

\begin{tabular}{|c|c|c|c|}
\hline $\begin{array}{c}\text { Sample } \\
\text { code }\end{array}$ & $\begin{array}{c}\text { Primer } \\
(10-800 \mathrm{bp})\end{array}$ & $\begin{array}{c}\text { Sequence accession } \\
\text { description }\end{array}$ & $\begin{array}{c}\text { Sequence } \\
\text { identity }\end{array}$ \\
\hline L3 & $10 \mathrm{~F}$ & $\begin{array}{c}\text { Acinetobacter pittii PHEA-2 } \\
\text { chromosome, complete } \\
\text { genome }\end{array}$ & $97 \%$ \\
& $800 \mathrm{R}$ & $\begin{array}{c}\text { NCBI Reference Sequence: } \\
\text { NC_016603.1 }\end{array}$ & \\
\hline L14 & $10 \mathrm{~F}$ & $\begin{array}{c}\text { Acinetobacter pittii PHEA-2 } \\
\text { chromosome, complete } \\
\text { genome }\end{array}$ & $97 \%$ \\
& $800 \mathrm{R}$ & $\begin{array}{c}\text { NCBI Reference Sequence: } \\
\text { NC_016603.1 }\end{array}$ & \\
\hline
\end{tabular}

\begin{tabular}{|c|c|c|c|}
\hline L16 & $\begin{array}{c}10 \mathrm{~F} \\
800 \mathrm{R}\end{array}$ & $\begin{array}{c}\text { Stenotrophomonas } \\
\text { maltophilia } \text { K279a complete } \\
\text { genome, strain K279a } \\
\text { NCBI Reference Sequence: } \\
\text { NC_010943.1 }\end{array}$ & $\begin{array}{l}99 \% \\
99 \%\end{array}$ \\
\hline L17 & $\begin{array}{c}10 \mathrm{~F} \\
800 \mathrm{R}\end{array}$ & $\begin{array}{c}\text { Stenotrophomonas } \\
\text { maltophilia K279a complete } \\
\text { genome, strain K279a } \\
\text { NCBI Reference Sequence: } \\
\text { NC_010943.1 }\end{array}$ & $\begin{array}{l}99 \% \\
99 \%\end{array}$ \\
\hline L19 & $\begin{array}{c}10 \mathrm{~F} \\
800 \mathrm{R}\end{array}$ & $\begin{array}{c}\text { Stenotrophomonas } \\
\text { maltophilia } \text { K279a complete } \\
\text { genome, strain K279a } \\
\text { NCBI Reference Sequence: } \\
\text { NC_010943.1 }\end{array}$ & $\begin{array}{l}99 \% \\
99 \%\end{array}$ \\
\hline L20 & $\begin{array}{c}10 \mathrm{~F} \\
800 \mathrm{R}\end{array}$ & $\begin{array}{c}\text { Acinetobacter baumannii } \\
\text { strain AB030, complete } \\
\text { genome } \\
\text { NCBI Reference Sequence: } \\
\text { NZ_CP009257.1 }\end{array}$ & $\begin{array}{l}96 \% \\
97 \%\end{array}$ \\
\hline L25 & $\begin{array}{c}10 \mathrm{~F} \\
800 \mathrm{R}\end{array}$ & $\begin{array}{c}\text { Stenotrophomonas } \\
\text { maltophilia K279a complete } \\
\text { genome, strain K279a } \\
\text { NCBI Reference Sequence: } \\
\text { NC_010943.1 }\end{array}$ & $\begin{array}{l}99 \% \\
99 \%\end{array}$ \\
\hline
\end{tabular}

\section{Conclusion}

Nowadays, the use of lipases in industries is becoming increasingly important. Extensive and persistent screening for new indigenous microorganisms with improved lipase abilities will lead to faster ways to upgrade the process. With the findings, we obtained three strains of best lipase producers from oil-contaminated soils in oil mills. To obtain maximum production of extracellular lipases, we need to control the best physico-chemical environment that greatly influences the enzyme production. So, the present study requires the optimization of the lipase-production conditions for further industrial applications.

\section{Acknowledgements}

Special thanks to the Department of Biotechnology, Mandalay Technologial University and Biotechnology Research Department, Kyaukse for giving the opportunity to perform this study and for providing the laboratory facilities.

\section{References}

[1] Gilham, D., and R. Lehner. 2005. Techniques to measure lipase and esterase activity in vitro. Methods 36: 139147.

[2] Beisson, F., V. Arondel, and R. Verger. 2000. Assaying Arabidopsis lipase activity. Biochemical Society Transactions 28 (6): 773-775.

[3] Arpigny, J. L., and K.E. Jaeger. 1999. Bacterial lipolytic enzymes: classification and properties. Biochem. J. 343: 177-183.

[4] Jaeger, K.E, S. Ransac, B. W. Dijkstra, C. Colson,M. van Heuvel, and O. Misset. 1994. Bacterial Lipases. FEMS Microbiology Reviews 15: 29-63.

[5] K.V.V.S.N. Bapiraju, P. Sujatha, P. Ellaiah, and T. Ramana, Afr. J. of Biot., 2004, 3 , 618-621. 
[6] T. Achamman, M.K. Monoj, A. Valsa, S. Mohan, and R. Manjula, Ind. J. Microbiol., 2003, 43, 67 - 69.

[7] Fojan, P., P.H. Jonson, M.T.N. Petersen, and S.B. Petersen. 2000. What distinguishes an esterase from a lipase: A novel structural approach. Biochimie 82: 10331041.

[8] J. Hosek, P. Svastova, M. Moravkova, I. Pavlik and M. Bartos, Veterinarni Medicina, 2006, 51, 180-192.

[9] Pissamai Powedchagun, Hideyuki Suzuki and Sirirat Rengpipat, J. Sci. Technol, 2011, 33, 1-8.

[10]E. Mobarak-Qamsari, R. Kasra-Kermanshahi, Z. Moosavi-nejad, Iran. J. Microbiol., 2011, 3, 92-98.

[11] K.E. Jaeger, T .Eggert, Curr. Opinion Biotechnol.,1998, 13, 390-397.

\section{Author Profile}

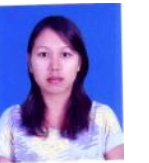

Ms. Khaing Phyo Wai is a $\mathrm{PhD}$ student at the department of Biotechnology, Mandalay Technological University. She was born in Myittha, Kyaukse Township, Mandalay Region, Republic of the Union of Myanmar. Her date of birth is September 23, 1985 and she is now 32 years old. She received the Degree of Bachelor of Science (Biotechnology) from Yangon Technological University, Myanmar in 2006. She also held Master Degree from Mandalay Technological University, Myanmar in 2010. Currently, she is doing her PhD research at the department of Biotechnology, Mandalay Technlogical University. She also has work experiences in the fields of "Microbial Enzyme Activity of Trichoderma sp." and "Antimicrobial Activity of Alcaligenes sp.". 